\title{
DEMOGRAPHIC RESPONSE TO SHADING AND DEFOLIATION IN TWO WOODLAND ORCHIDS
}

\author{
Richard P. Shefferson ${ }^{1, *}$, Tiiu Kull ${ }^{2)} \&$ Kadri Tali ${ }^{2)}$ \\ 1) Department of Integrative Biology, 3060 VLSB \#3140, University of California, Berkeley, CA 94720, USA; \\ *) Corresponding author, present address: Forestry and Forest Products Research Institute, 1 Matsunosato, \\ Tsukuba 305-8687 Japan; e-mail dormancy@gmail.com \\ 2) Institute of Zoology and Botany, Estonian Agricultural University, Riia 181, Tartu 51014, Estonia
}

\begin{abstract}
Many woodland herbs are long-lived, clonal geophytes that have evolved life histories favoring survival over reproduction. We examined the life history responses of natural populations of two woodland orchid species, Cypripedium calceolus and Cephalanthera longifolia to defoliation and heavy shading conducted early in the growing seasons of 2002 and 2003. We asked whether, in view of the importance of growth for the survival of geophytes, treated plants were more likely to exhibit reduced flowering than reduced vegetative growth in the seasons following treatment. We also asked whether plants would suffer reduced ramet performance. Both treatments led to significant declines in flower number per ramet, number of leaves per ramet, and mean ramet height relative to controls in Cypripedium. However, in Cephalanthera, only shaded plants exhibited significant declines in flower number per ramet, and only defoliated plants exhibited declines in mean ramet height. The number of ramets per plant did not decline relative to controls in either species. Thus, these orchids, especially Cypripedium, appeared to allocate resources preferentially to vegetative growth functions over sexual reproduction. Per-plant variation in leaf and flower number per ramet, as well as in mean ramet height, consistently declined in response to treatment, significantly so in the case of mean ramet height, suggesting that ramets became more similar within genets. These results suggest both similarities and differences in the ways in which Cephalanthera and Cypripedium mobilize resources in response to stress.
\end{abstract}

Keywords: Cephalanthera longifolia, Cypripedium calceolus, Geophytes, Life history trade-offs, Perennials, Orchidaceae, Resource allocation

Nomenclature: TUTIN T.G. et al. (1968-1993)

\section{INTRODUCTION}

Life history trade-offs are of great importance to woodland herbs, which are generally perennial and grow clonally (WHIGHAM 2004). The fitness of long-lived organisms is most sensitive to changes in adult survival (SILVERTOWN et al. 1993, SATHER \& BAKKE 2000), and adult survival in such organisms is generally invariant (GAILLARD \& YOCCOZ 2003), suggesting that it has a higher priority than reproduction in resource allocation (GLAZIER 2002). Furthermore, in clonal plants, adult survival is a function of growth, suggesting that any life history trade-offs with growth will also affect plant survival (CHESSON \& PETERSON 2002). In contrast, flowering and fruiting often have relatively little impact on population growth and persistence in perennials (BALTZER et al. 2002).

The effects of shading and herbivory on allocation patterns to life history functions are not always predictable (COLLINS \& PICKETT 1988a,b, VAN DER MEIJDEN et al. 2000, RUIZ et al. 2002). Clonal plants gain a greater ability to endure environmental stochasticity as more 
ramets occupy the surrounding habitat, thus buffering survival against unfavorable conditions (SUTHERLAND \& STILLMAN 1988, HUTCHINGS 1999, Li et al. 2000). However, clonal plants differ in physiological integration, with some species hoarding resources in the best ramets during times of stress and others sharing resources equitably between ramets (MARSHALL \& PRICE 1997, DERNER \& BRISKE 1998). Furthermore, within-population variation in resource acquisition and individual differences in resource allocation patterns may result in unexpected correlations between life history traits (DE JONG 1993), suggesting trade-offs where there are none, particularly in observational studies.

Storage of past photosynthate may reduce annual variation in survival by creating a bank of useable carbon reserves for times of stress (STANCATO et al. 2001). By diminishing the current photosynthetic capacity of a plant, herbivory and harvesting decrease the amount of photosynthate that may be stored for future use in sprout and flower development. Such resource losses may manifest themselves as reductions in quantity and/or quality not only of seeds and reproductive structures (STOWE et al. 2000), but also of leaves and other vegetative structures. Furthermore, herbivory may induce greater allocation to defense, leaving fewer resources for growth and reproduction (RUIZ et al. 2002). Changes in resource allocation deriving from defoliation may be observable even many years later (METZGER \& SCHULTZ 1984). Shading, by decreasing the amount of possible photosynthesis, may affect resource allocation in similar ways. However, as resource allocation in response to stress may differ by species, mobilization of stored resources may also differ, potentially leading to unexpected demographic responses at both the ramet and whole-plant levels.

Here, we experimentally shaded or defoliated plants in natural populations of the long-lived clonal species Cypripedium calceolus and Cephalanthera longifolia in the Baltic-coast of Estonia, to ascertain the life history context of response to imposed stress in woodland herbs. We asked two questions: (1) Do plants respond to eliminated or reduced photosynthesis with preferential allocation to sexual reproduction or vegetative growth? (2) Do plants share the demographic consequences of stress among all ramets, or "spare" the best ramets at the expense of the worst?

\section{MATERIALS AND METHODS}

\section{Study species and field sites}

Cypripedium calceolus and Cephalanthera longifolia are globally widespread though locally rare geophytes, occurring from Great Britain and Scandinavia in the northwest, to Spain in the southwest, and east to Japan (SUMMERHAYES 1968, KULL 1999). Cephalanthera longifolia also extends into northern Africa, the Middle East, and southwestern Asia (DAFNI \& IVRI 1981, WORLD CONSERVATION UNION 1963). These taxa are listed on CITES Appendix II (WORLD CONSERVATION UNION 1963) and receive special protection throughout Europe and Russia through a series of multinational European treaties (KULL 1999). They typically occur in northern forests, both coniferous and deciduous, and pollination is by deceit of insect vectors. The tiny seeds lack nutritional reserves, requiring impregnation by the appropriate mycorrhizal fungi for germination and growth (FULLER 1933, CURTIS 1943, 1959). In Cypripedium calceolus, the perennating structure is a creeping rhizome, with annual increments of 0.5-1.1 cm (CURTIS 1954, KULL 1987, KULL \& KULL 
1991). A typical rhizome may have as many as 20 annual increments of growth, with the oldest increments decaying at the proximal end of the rhizome (KULL \& KULL 1991). In Cephalanthera longifolia, the rhizome is also short, extending only $0.1 \mathrm{~cm}$ per year (KULL \& TUULIK 1994, SUMMERHAYES 1968). In both species the above-ground shoots are annual, starting to grow in May, flowering in June and withering in August.

Cypripedium individuals, from two Estonian populations, referred to as Muhu and Varangu, and Cephalanthera individuals from three populations, referred to as Kolga, Laelatu, and Sarapiku, were experimentally manipulated in 2002 and 2003, and monitored again in 2003 and 2004. Due to low densities of Cypripedium and Cephalanthera sprouts at each site, individuals, or genets, were defined as all sprouts occurring within $20 \mathrm{~cm}$ of each other. The field sites were woodland communities in western and central Estonia, lying in the European boreonemoral zone. The Muhu population lies in an alvar pine forest on the Baltic island of Muhu. Canopy species include Pinus sylvestris, Betula pendula, Fraxinus excelsior and Corylus avellana, and the average percentage of light reaching through the canopy to the herb layer is $24 \%$. The herb layer is species-rich (coverage $70 \%$ ) and dominated by Brachypodium pinnatum, Rubus saxatilis and Melica nutans, and bryophyte cover is $15 \%$ of the area. The Varangu population lies in a drained peatland spruce forest in central Estonia, close to a chalk quarry, with $18 \%$ sunlight at ground level. Herb cover is only $30 \%$ with dominance by Cypripedium calceolus, and bryophyte cover reaches $95 \%$. Kolga is a pine forest on limestone bedrock, with 30\% light penetration. The forest lacks a second stratum, but includes Rubus saxatilis, Sesleria caerulea, Festuca ovina, Filipendula vulgaris and Convallaria majalis. Laelatu is a species-rich wooded meadow with Quercus robur, Fraxinus excelsior and Populus tremula dominating the overstorey, and Carex vaginata, Brachypodium pinnatum, Aegopodium podagraria, Festuca arundinacea, Molinia caerulea, Pimpinella saxifraga and several orchid species occurring in the herb layer. Forty percent of sunlight reaches the herb layer. Sarapiku is a former pasture replaced by a sparse pine forest and juniper bushes, with $40 \%$ light infiltration to the herb layer. The soil layer is very thin and remains fairly dry in summer. In some parts, bare limestone is exposed. The herb layer is dominated by Sesleria caerulea, Anthyllis vulneraria, Fragaria vesca and Inula salicina, and bryophyte cover is $50 \%$.

\section{Experimental methods}

Early in spring 2002, we chose substantial portions of each population for manipulation and divided plants between two treatments (shading or defoliation) and a control treatment, in roughly equal proportions within each population. In the Muhu population of Cypripedium calceolus, 45 plants were chosen, of which 15 each became controls, shaded, and defoliated plants. In the Varangu population, 61 plants were chosen, and 20 each were assigned to the control and defoliated treatments, while 21 were assigned to the shaded treatment. In the Kolga population of Cephalanthera longifolia, a total of 16 were chosen as controls, 17 for defolation, and 15 for shading. In Laelatu, 15 plants were assigned to each treatment, and in Sarapiku, 19 plants were assigned to the control group, while 15 each were assigned to each treatment. Although small population sizes prevented us from controlling for plant size, we 


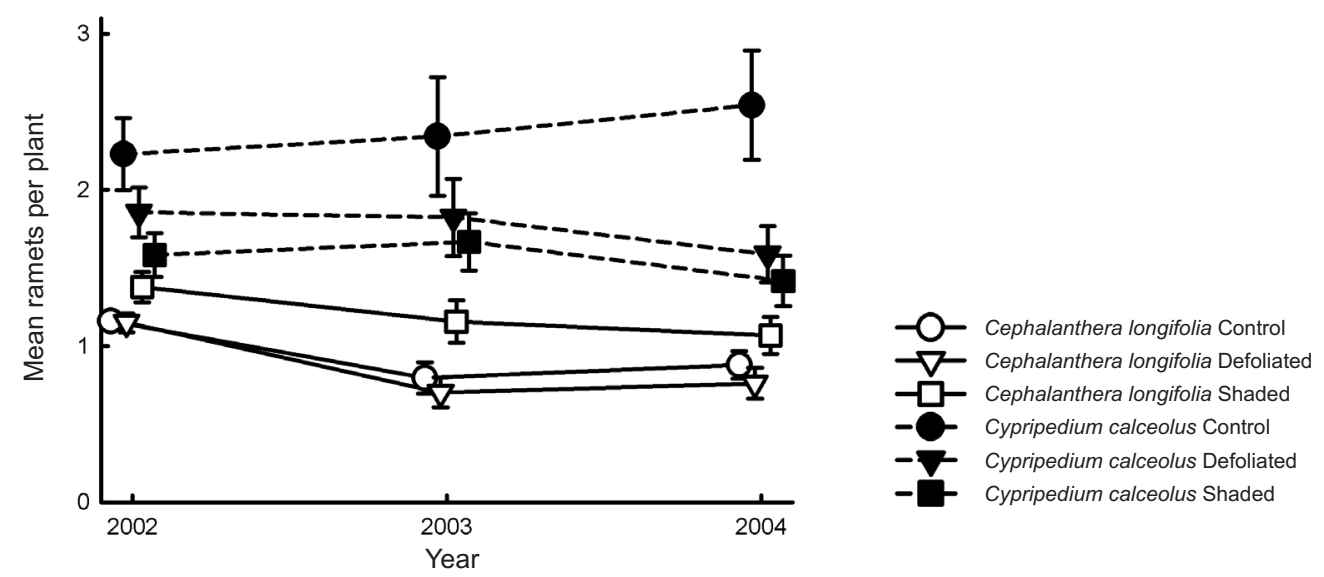

Fig. 1. Clonal growth of Cypripedium calceolus and Cephalanthera longifolia plants in response to shading and defoliation, measured as the number of ramets per plant. Measured immediately prior to treatment (2002), and one (2003) and two years after (2004), always at the start of the growing season.

attempted to avoid bias by including plants of all sizes within each population in each treatment.

In the shading treatment, a teepee-style frame made of two or three wooden stakes was placed over and around each plant. Black shade cloth, or sometimes green shade cloth when supply of black shade cloth was low, was then wrapped around the plant to reduce the light entering by at least $75 \%$. These shade devices were left over treated plants for two years and periodically checked over that time. In the defoliation treatment, we fully removed the plant's ramets each year at soil level prior to full leaf elongation. Both shaded and defoliated plants were marked with uniquely identified stakes, as were all controls. All manipulations were performed early in the growing season in 2002 and 2003, so as to minimize the amount of experimentally unrestricted photosynthesis possible for the plant. We measured all plants immediately prior to the first treatment (2002), and in spring of each of the following two years (2003 and 2004), recording the numbers and heights of ramets and the number of leaves and flowers per ramet, for all plants. In all cases, plants were monitored throughout the growing season in case of later sprouting, herbivory, or other unexpected events. In no cases, however, did we observe later sprouting.

\section{Analytical methods}

Analyses included repeated measures MANOVAs of the following characteristics per plant: number of ramets, number of leaves per ramet, number of flowers per ramet, mean ramet height, and within-genet (i.e., per ramet) standard deviations of the latter three characteristics. Analyses of the coefficients of variation (CV) of numbers of leaves and flowers, and mean ramet height, per plant were also conducted, but yielded results consistent with those of the standard deviations of the same variables, and are not discussed further. We analyzed all populations with fully factorial MANOVAs including time, population, and 
Table 1. Strength of time, treatment, and population effects and their interactions in tests of the response of characteristics of plants to defoliation and shading in Cypripedium calceolus and Cephalanthera longifolia, using multivariate repeated-measures ANOVA. Characteristics include the number of ramets per plant, the numbers of leaves and flowers per ramet per plant, and mean ramet height per plant. Results presented are generally $F$-tests, except for Wilks' Lambda tests, which are indicated with an asterisk $\left({ }^{*}\right)$ next to the resulting $F$-statistic.

\begin{tabular}{|c|c|c|c|c|c|c|}
\hline \multirow[b]{2}{*}{ Effect } & \multicolumn{3}{|c|}{ Cypripedium calceolus } & \multicolumn{3}{|c|}{ Cephalanthera longifolia } \\
\hline & $F$ & d.f. & $P \leq$ & F & d.f. & $P \leq$ \\
\hline \multicolumn{7}{|l|}{ Number of ramets per plant } \\
\hline Intercept & 270.81 & 1,99 & 0.001 & 540.35 & 1,130 & 0.001 \\
\hline Population & 1.19 & 1,99 & 0.278 & 11.93 & 2,130 & 0.001 \\
\hline Treatment & 5.12 & 2,99 & 0.008 & 5.36 & 2,130 & 0.006 \\
\hline Treatment $\times$ Population & 2.07 & 2,99 & 0.132 & 0.45 & 4,130 & 0.771 \\
\hline Time & 0.66 & 2,98 & 0.521 & 26.05 & 2,129 & 0.001 \\
\hline Time $\times$ Population & 1.37 & 2,98 & 0.259 & 4.31* & 4,258 & 0.002 \\
\hline Time $\times$ Treatment & $1.52 *$ & 4,196 & 0.198 & $0.50 *$ & 4,258 & 0.736 \\
\hline Time $\times$ Population $\times$ Treatment & $1.56^{*}$ & 4,196 & 0.186 & $1.58^{*}$ & 8,258 & 0.132 \\
\hline
\end{tabular}

Number of leaves per ramet

$\begin{array}{lrllrrr}\text { Intercept } & \mathbf{2 1 7 9 . 4 4} & \mathbf{1 , 9 8} & \mathbf{0 . 0 0 1} & \mathbf{9 4 9 . 1 1} & \mathbf{1 , 1 3 0} & \mathbf{0 . 0 0 1} \\ \text { Population } & 1.31 & 1,98 & 0.256 & \mathbf{1 6 . 3 8} & \mathbf{2 , 1 3 0} & \mathbf{0 . 0 0 1} \\ \text { Treatment } & \mathbf{7 . 7 5} & \mathbf{2 , 9 8} & \mathbf{0 . 0 0 1} & 0.35 & 2,130 & 0.703 \\ \text { Treatment } \times \text { Population } & 0.13 & 2,98 & 0.874 & 0.71 & 4,130 & 0.589 \\ \text { Time } & \mathbf{4 1 . 5 0} & \mathbf{2 , 9 7} & \mathbf{0 . 0 0 1} & \mathbf{2 3 . 4 4} & \mathbf{2 , 1 2 9} & \mathbf{0 . 0 0 1} \\ \text { Time } \times \text { Population } & \mathbf{4 . 5 3} & \mathbf{2 , 9 7} & \mathbf{0 . 0 1 3} & \mathbf{5 . 7 1 *} & \mathbf{4 , 2 5 8} & \mathbf{0 . 0 0 1} \\ \text { Time } \times \text { Treatment } & \mathbf{1 1 . 1 0 *} & \mathbf{4 , 1 9 4} & \mathbf{0 . 0 0 1} & 0.91^{*} & 4,258 & 0.456 \\ \text { Time } \times \text { Population } \times \text { Treatment } & 0.17^{*} & 4,194 & 0.951 & 0.56^{*} & 8,258 & 0.807\end{array}$

Number of flowers per ramet

$\begin{array}{lrrrrrr}\text { Intercept } & \mathbf{1 4 9 . 7 8} & \mathbf{1 , 9 8} & \mathbf{0 . 0 0 1} & \mathbf{2 1 6 . 4 4} & \mathbf{1 , 1 3 0} & \mathbf{0 . 0 0 1} \\ \text { Population } & 1.34 & 1,98 & 0.249 & \mathbf{1 4 . 2 3} & \mathbf{2 , 1 3 0} & \mathbf{0 . 0 0 1} \\ \text { Treatment } & \mathbf{2 1 . 1 7} & \mathbf{2 , 9 8} & \mathbf{0 . 0 0 1} & 1.93 & 2,130 & 0.150 \\ \text { Treatment } \times \text { Population } & 0.30 & 2,98 & 0.743 & \mathbf{3 . 9 9} & \mathbf{4 , 1 3 0} & \mathbf{0 . 0 0 4} \\ \text { Time } & \mathbf{3 6 . 2 0} & \mathbf{2 , 9 7} & \mathbf{0 . 0 0 1} & \mathbf{3 7 . 1 3} & \mathbf{2 , 1 2 9} & \mathbf{0 . 0 0 1} \\ \text { Time } \times \text { Population } & 1.23 & 2,97 & 0.297 & \mathbf{8 . 5 1 *} & \mathbf{4 , 2 5 8} & \mathbf{0 . 0 0 1} \\ \text { Time } \times \text { Treatment } & \mathbf{1 0 . 6 4}^{*} & \mathbf{4 , 1 9 4} & \mathbf{0 . 0 0 1} & \mathbf{3 . 1 4} & \mathbf{4 , 2 5 8} & \mathbf{0 . 0 1 5} \\ \text { Time } \times \text { Population } \times \text { Treatment } & 0.71^{*} & 4,194 & 0.585 & \mathbf{2 . 9 2 *} & \mathbf{8 , 2 5 8} & \mathbf{0 . 0 0 4}\end{array}$

Mean ramet height per plant

\begin{tabular}{lrllrrr} 
Intercept & $\mathbf{7 . 9 4}$ & $\mathbf{1 , 9 9}$ & $\mathbf{0 . 0 0 1}$ & $\mathbf{6 8 7 . 5 4}$ & $\mathbf{1 , 1 3 0}$ & $\mathbf{0 . 0 0 1}$ \\
Population & $\mathbf{5 1 . 5 5}$ & $\mathbf{1 , 9 9}$ & $\mathbf{0 . 0 0 1}$ & $\mathbf{2 4 . 0 9}$ & $\mathbf{2 , 1 3 0}$ & $\mathbf{0 . 0 0 1}$ \\
Treatment & $\mathbf{1 5 . 3 8}$ & $\mathbf{2 , 9 9}$ & $\mathbf{0 . 0 0 1}$ & $\mathbf{9 . 7 3}$ & $\mathbf{2 , 1 3 0}$ & $\mathbf{0 . 0 0 1}$ \\
Treatment $\times$ Population & $\mathbf{1 2 . 5 8}$ & $\mathbf{2 , 9 9}$ & $\mathbf{0 . 0 0 1}$ & $\mathbf{2 . 5 9}$ & $\mathbf{4 , 1 3 0}$ & $\mathbf{0 . 0 4 0}$ \\
Time & $\mathbf{2 0 5 . 9 1}$ & $\mathbf{2 , 9 8}$ & $\mathbf{0 . 0 0 1}$ & $\mathbf{7 5 . 0 8}$ & $\mathbf{2 , 1 2 9}$ & $\mathbf{0 . 0 0 1}$ \\
Time $\times$ Population & $\mathbf{5 1 . 8 3}$ & $\mathbf{2 , 9 8}$ & $\mathbf{0 . 0 0 1}$ & $\mathbf{1 5 . 7 5 *}$ & $\mathbf{4 , 2 5 8}$ & $\mathbf{0 . 0 0 1}$ \\
Time $\times$ Treatment & $\mathbf{1 2 . 2 6 *}$ & $\mathbf{4 , 1 9 6}$ & $\mathbf{0 . 0 0 1}$ & $\mathbf{2 0 . 4 4 *}$ & $\mathbf{4 , 2 5 8}$ & $\mathbf{0 . 0 0 1}$ \\
Time $\times$ Population $\times$ Treatment & $2.02^{*}$ & 4,196 & 0.093 & $\mathbf{2 . 4 4 *}$ & $\mathbf{8 , 2 5 8}$ & $\mathbf{0 . 0 1 5}$ \\
\hline
\end{tabular}


Table 2. Strength of time, treatment, and population effects and their interactions in tests of the response of the standard deviations of characteristics of plants to defoliation and shading in Cypripedium calceolus and Cephalanthera longifolia, using multivariate repeated-measures ANOVA. Characteristics include the standard deviations of the numbers of leaves per ramet, flowers per ramet, and mean ramet height per plant. Results presented are generally $F$-tests, except for Wilks' Lambda tests, which are indicated with an asterisk (*) next to the resulting $F$-statistic.

\begin{tabular}{|c|c|c|c|c|c|c|}
\hline \multirow[b]{2}{*}{ Effect } & \multicolumn{3}{|c|}{ Cypripedium calceolus } & \multicolumn{3}{|c|}{ Cephalanthera longifolia } \\
\hline & $F$ & d.f. & $P \leq$ & $F$ & d.f. & $P \leq$ \\
\hline \multicolumn{7}{|c|}{ s.d. number of leaves per ramet per plant } \\
\hline Intercept & 86.59 & 1,99 & 0.001 & 26.34 & 1,130 & 0.001 \\
\hline Population & 0.11 & 1,99 & 0.742 & 3.66 & 2,130 & 0.028 \\
\hline Treatment & 2.39 & 2,99 & 0.097 & 1.27 & 2,130 & 0.284 \\
\hline Treatment $\times$ Population & 0.61 & 2,99 & 0.545 & 2.13 & 4,130 & 0.080 \\
\hline Time & 5.18 & 2,98 & 0.007 & 0.05 & 2,129 & 0.953 \\
\hline Time $\times$ Population & 1.29 & 2,98 & 0.281 & $0.25^{*}$ & 4,258 & 0.912 \\
\hline Time $\times$ Treatment & $0.92 *$ & 4, 196 & 0.455 & $1.90^{*}$ & 4,258 & 0.110 \\
\hline Time $\times$ Population $\times$ Treatment & $1.85^{*}$ & 4,196 & 0.121 & $1.10^{*}$ & 8,258 & 0.367 \\
\hline
\end{tabular}

s.d. number of flowers per ramet per plant

\begin{tabular}{|c|c|c|c|c|c|c|}
\hline Intercept & 16.01 & 1,99 & 0.001 & 9.99 & 1,128 & 0.002 \\
\hline Population & 0.21 & 1,99 & 0.647 & 0.79 & 2,128 & 0.453 \\
\hline Treatment & 3.95 & 2,99 & 0.022 & 0.26 & 2,128 & 0.773 \\
\hline Treatment $\times$ Population & 0.12 & 2,99 & 0.890 & 0.80 & 4,128 & 0.527 \\
\hline Time & 3.41 & 2,98 & 0.037 & 2.23 & 2,127 & 0.112 \\
\hline Time $\times$ Population & 2.08 & 2,98 & 0.131 & $1.04 *$ & 4,254 & 0.387 \\
\hline Time $\times$ Treatment & $0.71 *$ & 4, 196 & 0.583 & $1.44^{*}$ & 4,254 & 0.220 \\
\hline Time $\times$ Population $\times$ Treatment & $1.15^{*}$ & 4,196 & 0.336 & $0.79 *$ & 8,254 & 0.613 \\
\hline \multicolumn{7}{|l|}{ s.d. ramet height per plant } \\
\hline Intercept & 93.51 & 1,99 & 0.001 & 30.78 & 1,130 & 0.001 \\
\hline Population & 14.40 & 1,99 & 0.001 & 3.59 & 2,130 & 0.030 \\
\hline Treatment & 8.51 & 2, 99 & 0.001 & 4.83 & 2,130 & 0.010 \\
\hline Treatment $\times$ Population & 2.75 & 2,99 & 0.069 & 3.47 & 4,130 & 0.010 \\
\hline Time & 18.41 & 2,98 & 0.001 & 3.46 & 2,129 & 0.035 \\
\hline Time $\times$ Population & 3.01 & 2,98 & 0.054 & $1.39 *$ & 4,258 & 0.237 \\
\hline Time $\times$ Treatment & $3.44 *$ & 4,196 & 0.010 & $3.57 *$ & 4,258 & 0.008 \\
\hline Time $\times$ Population $\times$ Treatment & $0.23 *$ & 4,196 & 0.920 & $0.81^{*}$ & 8,258 & 0.594 \\
\hline
\end{tabular}

treatment. Whenever Chi-square tests of sphericity were not significant for a particular response, we used univariate, unadjusted $F$-tests. Otherwise, we used Wilks' lambda, in particular in some tests of interactions with time, and describe the results with $F$ statistics. Although Pillai's trace, Hotelling-Lawley, and Roy's max root $F$-statistics were also calculated, they always yielded results consistent with Wilks' lambda, and are not discussed further. In each case, a significant time $\times$ treatment interaction together with greater declines over time of treated plants relative to controls indicated an experimentally-induced reduction in that character. 

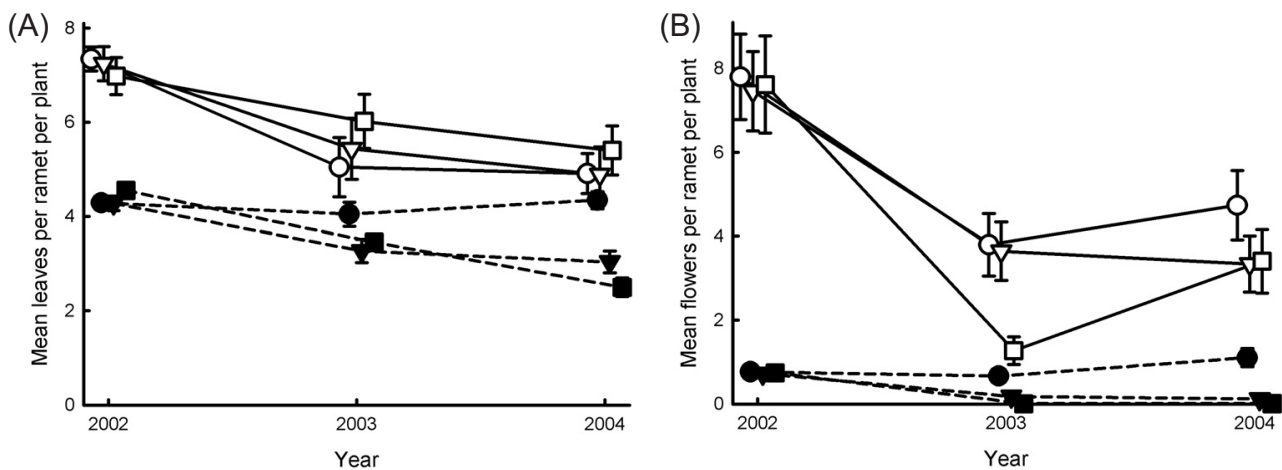

Fig. 2. Ramet-level vegetative (A) and reproductive (B) response of Cypripedium calceolus and Cephalanthera longifolia plants to shading and defoliation, measured as the mean number of leaves and flowers per ramet per plant, respectively. Measured immediately prior to treatment (2002), and one (2003) and two years after (2004), always at the start of the growing season. Legend as in Fig. 1.

\section{RESULTS}

\section{Cypripedium calceolus}

Clonal growth of Cypripedium calceolus appeared relatively unaffected by treatment. Averaged across all populations, neither shading nor defoliation significantly affected ramet number after one year (time $\times$ treatment: $F_{4,196}=1.52, P=0.198$, Table 1). In contrast, ramet-level growth was dramatically affected by treatment. Treated plants in both populations suffered significant declines in leaf growth per ramet relative to controls (time $\times$ treatment: $F_{4,194}=11.10, P<10^{-3}$, Table 1, Fig. 2A). Likewise, the number of flowers per ramet declined significantly relative to controls (time $\times$ treatment: $F_{4,194}=10.64, P<10^{-3}$, Table 1 , Fig. 2B), as did the mean ramet height per plant (time $\times$ treatment: $F_{4,196}=12.26, P<10^{-3}$, Table 1, Fig. 3A). In repeated measures analyses of the standard devations of mean number of leaves and flowers per ramet per plant, and mean ramet height per plant, only mean ramet height differed significantly by treatment over time (time $\times$ treatment: $F_{4,196}=3.44, P=$ 0.010 , Table 2). However, the standard deviations of all three parameters declined over time in treated plants relative to controls (Fig. 3B, 4A, and 4B), indicating that ramets within the same plant become more similar to each other after treatment.

\section{Cephalanthera longifolia}

Although Cephalanthera longifolia individuals had only one-third to one-half the number of ramets per plant as Cypripedium calceolus, ramet number did not decline significantly in treated plants relative to controls (time $\times$ treatment: $F_{4,258}=0.50, P=0.736$, Table 1, Fig. 1). The number of leaves per ramet did not decline significantly either (time $\times$ treatment: $F_{4,258}$ $=0.91, P=0.456$, Table 1, Fig. 2A). In contrast, shaded plants, though not defoliated plants, exhibited immediate significant declines in mean flowers per ramet (time $\times$ treatment: $F_{4,258}=3.14, P=0.015$, Table 1 , Fig. 2 B), while defoliated plants, not shaded plants, exhibited significant declines in mean ramet height (time $\times$ treatment: $F_{4,258}=20.44$, $P<10^{-3}$, Table 1, Fig. 3A). 

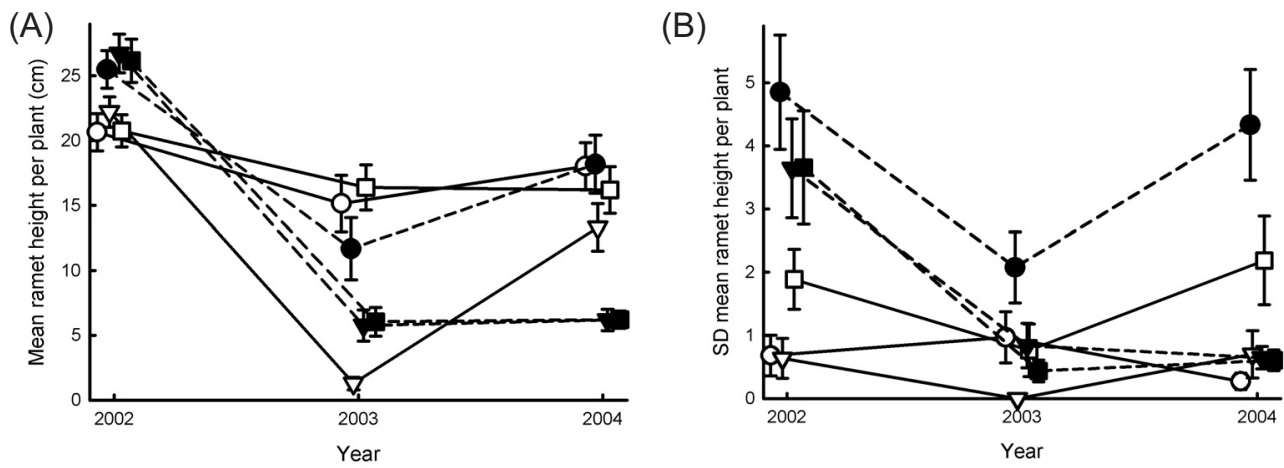

Fig. 3. Means (A) and variabilities (B) of ramet-level vegetative response of Cypripedium calceolus and Cephalanthera longifolia plants to shading and defoliation, measured as the mean height of ramets per plant. Measured immediately prior to treatment (2002), and one (2003) and two years after (2004), always at the start of the growing season. Legend as in Fig. 1.

As with Cypripedium calceolus, the standard deviation of ramet height per plant responded to treatment over time (time $\times$ treatment: $F_{4,258}=3.57, P=0.008$, Table 2), while the standard deviations of mean leaf and flower number per ramet per plant did not. However, this result was due to a significant decline in the standard deviation of ramet height per plant in treated plants relative to controls in 2003, followed by a significant increase in 2004 (Fig. 4B). Similar, though not significant declines in standard deviation in 2003, followed by increases in 2004, were observed in leaf and flower numbers per ramet per plant (Table 2, Fig. 4).

\section{DISCUSSION}

Studies of response to defoliation or shading among woodland orchids and other herbs are rare and generally focus on non-clonal species. Studies of ramet dynamics within clonal plants are particularly rare. A study of the European orchid Spiranthes spiralis, which stores photosynthate produced in one season for growth in the following season, revealed significant increases in seed production and mortality resulting from shading (WILLEMS et al. 2001). Shading results in reduced growth in Dactylorhiza fuchsii seedlings, though primarily through an initial decrease in root : shoot ratio (MCKENDRICK 1996). In both cases, however, the studied herbs are not truly clonal, and are not long-lived. In the case of the long-lived, clonal Podophyllum peltatum, ramets responded to defoliation by foregoing sexual reproduction in the following year (DE KROON et al. 1991), and, if separated from each other, by reducing rhizome growth rates (WHIGHAM \& CHAPA 1999).

Shading and defoliation resulted in significant loss to future sexual reproduction, evidenced through significantly greater declines in flower number per ramet of treated plants but no significant declines in ramet number per plant. This suggests that stored reserves of resources from one year are used preferentially for growth rather than for sexual reproduction in the following year in both species. A previous study of Cypripedium acaule suggested that while costs of reproduction may be relatively cheap in some woodland herbs, they are potentially most costly after the stress of defoliation (PRIMACK et al. 1994). Such patterns 
(A)

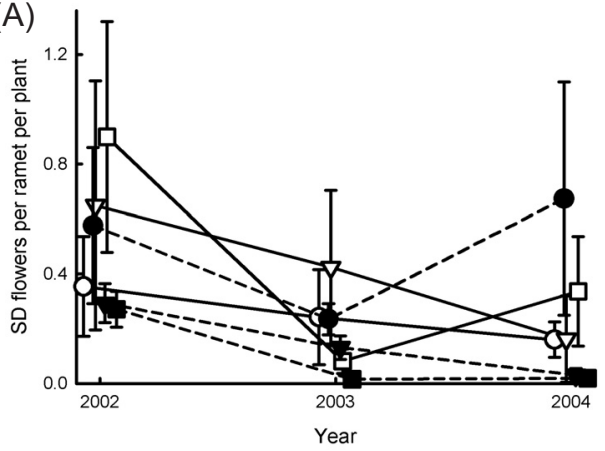

(B)

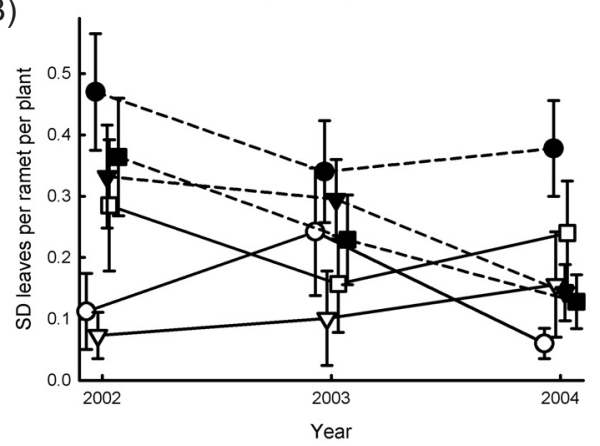

Fig. 4. Variability in ramet-level reproductive (A) and vegetative (B) response per plant of Cypripedium calceolus and Cephalanthera longifolia plants to shading and defoliation, measured as the standard deviation of flowers and leaves per ramet per plant, respectively. Measured immediately prior to treatment (2002), and one (2003) and two years after (2004), always at the start of the growing season. Legend as in Fig. 1.

probably relate to greater resource needs for sprout growth than for sexual reproduction (REEKIE et al. 2002), and the importance of survival in long-lived organisms. However, the effects of defoliation may also depend on when during the growing season plants are treated (GARCIA \& EHRLÉN 2002).

Defoliation and shading resulted in growth costs that generally appeared to "average out" among constituent ramets per plant. In both Cypripedium calceolus and Cephalanthera longifolia, treatment was immediately followed by a reduction in standard deviation of ramet-level characteristics, significantly so in the case of mean ramet height per plant, suggesting that these species respond to stress by mobilizing and allocating resources in such a way as to equalize the performance of ramets. Furthermore, in the Cypripedium calceolus populations, defoliation and shading also resulted in significant declines in leaves per ramet (Table 1). Such declines suggest that plants maintain a relatively constant number of ramets, and thus must average out resource shortfalls between them (cf. GARCIA \& EHRLÉN 2002).

Just as life history costs to sexual reproduction may be paid against two aspects of reproduction, quantity or quality of offspring (AMUNDSEN \& SLAGSVOLD 1998, STOWE et al. 2000), costs to future growth, and hence to vegetative reproduction, appear to fall into this dichotomy as well. These plants appear to favour a larger number of lower quality ramets over a smaller number of higher quality ramets. Under high physiological integration, the benefits of keeping many sprouts regardless of quality are numerous, including the spread of mortality risk and an increased ability to average out patchy conditions (CALLAGHAN et al. 1992, CHESSON \& PETERSON 2002). In the present study, keeping more ramets of lower quality may increase the chance of photosynthesizing by reducing the chance of complete defoliation and/or shading. This condition may represent bet-hedging, in which the variability in photosynthesis from year-to-year is reduced in order to maximize survival, and hence fitness (SiLVERTOWN et al. 1993, SLATKIN 1974, StUEFER et al. 1996). This further suggests that there may be a threshold level of acquired and stored resources that may be needed to sprout at all. Below this threshold, the result may be whole-plant dormancy, a condition observed in 
Cypripedium calceolus and related species (KULL 2002, LESICA \& STEELE 1994, SHEFFERSON et al. 2001).

However, responses also differed by species in a number of ways, suggesting that their response strategies to stress may be fundamentally different. Though leaves per ramet per plant declined significantly in Cypripedium plants, Cephalanthera was not signicantly affected (Fig. 2A). Furthermore, though flower number per ramet and mean ramet height declined significantly in treated Cypripedium plants, only defoliated Cephalanthera plants experienced reduced mean ramet height (Fig. 3A), and only shaded Cephalanthera plants experienced reduced flower numbers per ramet (Fig. 2B). The two species also differed in response in 2004, with shaded Cephalanthera longifolia plants consistently experiencing increased standard deviation in ramet-level characteristics following an initial decrease (Fig. 3B, 4A, and 4B). However, since we did not control for resource acquisition, some of these differing responses may be explainable by differing resource levels, different mycorrhizal partners and interactions, and other ecological factors. Further years of study, and study in sympatric sites, may further elucidate the full extent of the differences between species.

Acknowledgments: We would like to thank B. Baldwin, S.R. Beissinger, T. Bruns, P. Kindlmann, E.L. Simms, and two anonymous reviewers for help throughout the writing of this manuscript, and J.H. Willems for logistic help and discussions in the early stages of this project. This work was funded by Estonian SF grant 4833, the Budweiser Conservation Scholarship provided by the Anheuser-Busch Corporation in cooperation with the National Fish and Wildlife Foundation, the Furniss Foundation / American Orchid Society Graduate Fellowship, and generous support from the Dept. of Integrative Biology and the University of California Botanical Garden at the University of California at Berkeley.

\section{REFERENCES}

AMUNDSEN T. \& SLAGSVOLD T. (1998): Hatching asynchrony in great tits: a bet-hedging strategy? Ecology 79: 295-304.

BAltZer J.L., ReEKIE E.G., Hewlin H.L., TAYlor P.D. \& BOATES J.S. (2002): Impact of flower harvesting on the salt marsh plant Limonium carolinianum. Canad. J. Bot. 80: 841-851.

CALlaghan T.V., CARLSSON B.Å., JÓNSDÓTTIR I.S., SVENSSON B.M. \& JONASSON S. (1992): Clonal plants and environmental change: introduction to the proceedings and summary. Oikos 63: 341-347.

CHESSON P. \& PETERSON A.G. (2002): The quantitative assessment of the benefits of physiological integration in clonal plants. Evol. Ecol. Res. 4: 1153-1176.

COLLINS B.S. \& PICKETT S.T.A. (1988a): Demographic responses of herb layer species to experimental canopy gaps in a northern hardwoods forest. J. Ecol. 76: 437-450.

COLLINS B.S. \& PICKETT S.T.A. (1988b): Response of herb layer cover to experimental canopy gaps. Amer. Midl. Naturalist 119: 282-290.

CURTIS J.T. (1943): Germination and seedling development in five species of Cypripedium L. Amer. J. Bot. 30: 199-206.

CURTIS J.T. (1954): Annual fluctuation in rate of flower production by native Cypripediums during two decades. Bull. Torrey Bot. Club 81: 340-352.

CURTIS J.T. (1959): The vegetation of Wisconsin: an ordination of plant communities. University of Wisconsin Press, Madison.

DAFNI A. \& IVRI Y. (1981): The flower biology of Cephalanthera longifolia (Orchidaceae) - pollen limitation and facultative floral mimicry. Pl. Syst. Evol. 137: 229-240.

DE JONG G. (1993): Covariances between traits deriving from successive allocations of a resource. Funct. Ecol. 7: 75-83. 
DE Kroon H., Whigham D.F. \& WATSON M.A. (1991): Developmental ecology of mayapple: effects of rhizome severing, fertilization and timing of shoot senescence. Funct. Ecol. 5: 360-368.

DERNER J.D. \& BRISKE D.D. (1998): An isotopic (N-15) assessment of intraclonal regulation in C-4 perennial grasses: ramet interdependence, independence or both? J. Ecol. 86: 305-314.

Fuller A.M. (1933): Studies on the flora of Wisconsin. Part I: The orchids; Orchidaceae. Bull. Public Mus. Milwaukee 14: 1-284.

GAILLARD J.-M. \& YOCCOZ N.G. (2003): Temporal variation in survival of mammals: a case of environmental canalization? Ecology 84: 3294-3306.

GARCIA M.B. \& EHRLÉN J. (2002): Reproductive effort and herbivory timing in a perennial herb: fitness components at the individual and population levels. Amer. J. Bot. 89: 1295-1302.

GLAZIER D.S. (2002): Resource-allocation rules and the heritability of traits. Evolution 56: 1696-1700.

HuTCHINGS M. (1999): Clonal plants as cooperative systems: benefits in heterogeneous environments. Pl. Spec. Biol. 14: 1-10.

KULL T. (1987): Population ecology of Cypripedium calceolus L. In: LAASIMER L. \& KULL T. (eds.), The plant cover of the Estonian SSR: flora, vegetation, and ecology, Valgus, Tallinn, pp. 77-83.

KULL T. (1999): Cypripedium calceolus L. J. Ecol. 87: 913-924.

Kull T. (2002): Population dynamics of north temperate orchids. In: Kull T. \& Arditti J. (eds.), Orchid biology, reviews and perspecitves 8, Kluwer Academic Publishers, Dordrecht, pp. 139-165.

KUlL T. \& KULL K. (1991): Preliminary results from a study of populations of Cypripedium calceolus in Estonia. In: Wells T.C.E. \& Willems J.H. (eds.), Population ecology of terrestrial orchids, SPB Academic Publishing, The Hague, pp. 69-76.

Kull T. \& TUUliK T. (1994): Orchid studies on permanent plots. In: Kull T. (eds.), Orchid ecology and protection in Estonia, Tartu University Press, Tartu, pp. 35-42

LESICA P. \& STEELE B.M. (1994): Prolonged dormancy in vascular plants and implications for monitoring studies. Natural Areas J. 14: 209-212.

Li R., Werger M.J.A., DE KroOn H., During H.J. \& ZHONG Z.C. (2000): Interactions between shoot age structure, nutrient availability and physiological integration in the giant bamboo Phyllostachys pubescens. Pl. Biol. 2: 437-446.

MARSHALL C. \& PRICE E.A.C. (1997): Sectoriality and its implications for physiological integration. In: DE KROON H. \& VAN GROENENDAEL J. (eds.), The ecology and evolution of clonal plants, Backhuys Publishers, Leiden, pp. 79-107.

MCKENDRICK S.L. (1996): The effects of shading on seedlings of Orchis morio and Dactylorhiza fuchsii in chalk and clay soil. New Phytol. 134: 343-352.

METZGER F. \& SCHULTZ J. (1984): Understory response to 50 years of management of a northern hardwood forest in upper Michigan. Amer. Midl. Naturalist 112: 209-223.

PRIMACK R.B., MIAO S.L. \& BECKER K.R. (1994): Costs of reproduction in the pink lady's slipper orchid (Cypripedium acaule): defoliation, increased fruit production, and fire. Amer. J. Bot. 81: 1083-1090.

REEKIE E.G., BUDGE S. \& BALTZER J.L. (2002): The shape of the trade-off function between reproduction and future performance in Plantago major and Plantago rugelii. Canad. J. Bot. 80: 140-150.

RUIZ N., WARD D. \& SALTZ D. (2002): Responses of Pancratium sickenbergeri to simulated bulb herbivory: combining defence and tolerance strategies. J. Ecol. 90: 472-479.

SATHER B.-E. \& BAKKE O. (2000): Avian life history variation and contribution of demographic traits to the population growth rate. Ecology 81: 642-653.

Shefferson R.P., SANDERcock B.K., Proper J. \& Beissinger S.R. (2001): Estimating dormancy and survival of a rare herbaceous perennial using mark-recapture models. Ecology 82: 145-156.

Silvertown J., Franco M., PISANTy I. \& MendozA A. (1993): Comparative plant demography - relative importance of life-cycle components to the finite rate of increase in woody and herbaceous perennials. $J$. Ecol. 81: 465-476.

SLATKIN M. (1974): Hedging one's evolutionary bets. Nature 250: 704-705.

STANCATO G.C., MAZZAFERA P., \& BUCKERIDGE M.S. (2001): Effect of a drought period on the mobilisation of non-structural carbohydrates, photosynthetic efficiency and water status in an epiphytic orchid. $P l$. Physiol. Biochem. 39: 1009-1016. 
Stowe K.A., MARQuis R.J., Hochwender C.G. \& Simms E.L. (2000): The evolutionary ecology of tolerance to consumer damage. Annual Rev. Ecol. Syst. 31: 565-595.

STUEFER J.F., DE KROON H. \& DURING H.J. (1996): Exploitation of environmental heterogeneity by spatial division of labour in a clonal plant. Funct. Ecol. 10: 328-334.

SUMMERHAYES V.S. (1968): Wild orchids of Britain. Collins, London.

SUTHERLAND W.J. \& STILLMAN R.A. (1988): The foraging tactics of plants. Oikos 52: 239-244.

TUTIN T.G. et al. (eds.) (1968-1993): Flora europaea Ed. 1, 2. Cambridge University Press, Cambridge.

VAN DER MEIJDEn E., DE BOeR N.J. \& VAN DER VEEN-VAN WIJK C.A.M. (2000): Pattern of storage and regrowth in ragwort. Evol. Ecol. 14: 439-455.

WHIGHAM D. \& CHAPA A. (1999): Timing and intensity of herbivory: its influence on the performance of clonal woodland herbs. Pl. Spec. Biol. 14: 29-37.

WHIGHAM D.F. (2004): Ecology of woodland herbs in temperate deciduous forests. Annual Rev. Ecol. Evol. Syst. 35: 583-621.

Willems J.H., BALOUNOVÁ Z. \& KindLMANN P. (2001): The effect of experimental shading on seed production and plant survival of Spiranthes spiralis (Orchidaceae). Lindleyana 16: 31-37.

WORLD CONSERVATION UNION (1963): The Convention on International Trade in Endangered Species of Wild Fauna and Flora. The World Conservation Union (IUCN), Gland.

Received 4 November 2004, revision received and accepted 9 May 2005 